\title{
25 Research Square \\ Metabolic Differences Between Suaeda Salsa and Puccinellia Tenuiflora Under Saline-alkali Stress
}

\section{Qi Chen}

Nantong University

Huansong Xie

Nantong University

Guanyun Wei

Nantong University

Xiaorui Guo

Northeast Forestry University

Jian Zhang

Nantong University

Xueyan Lu ( $\square$ nefu20064764@126.com )

Northeast Agricultural University

Zhonghua Tang

Northeast Forestry University

\section{Research Article}

Keywords: Salt-alkali stress, Puccinellia tenuiflora, Suaeda salsa, Metabolomics, Tolerance

Posted Date: October 13th, 2021

DOI: https://doi.org/10.21203/rs.3.rs-892289/v1

License: (a) (i) This work is licensed under a Creative Commons Attribution 4.0 International License.

Read Full License 


\section{Abstract}

Background: Salinization of soil is an urgent problem that restricts agroforestry production and environment protection. Substantial accumulation of metal ion or high alkaline alters plant metabolites and may even cause plant death. In order to explore the differences in the response strategies between Suaeda salsa (S. salsa) and Puccinellia tenuiflora (P. tenuiflora), two main constructive species that survive in saline-alkali soil, their metabolic differences were characterized.

Result: Metabolomics was conducted to study the role of metabolic differences between $S$. salsa and $P$. tenuiflora under saline-alkali stress. A total of 68 significantly different metabolites were identified by GCMS, including 9 sugars, 13 amino acids, 8 alcohols, and 34 acids. A more detailed analysis indicated that $P$. tenuiflora utilizes sugars more effectively and may be salt-alkali tolerant via sugar consumption while $S$. salsa mainly utilizes amino acids, alcohols, and acids to resist salt-alkali stress. Measurement of phenolic compounds showed that more C6C3C6-compounds were accumulated in $P$. tenuiflora while more $\mathrm{C} 6 \mathrm{C} 1$-compounds, phenolic compounds that can be used to defense stress as signaling molecules, were accumulated in S. salsa.

Conclusion: Our observations suggest that $S$. salsa resists the toxicity of saline-alkali stress using aboveground organs and $P$. tenuiflora eliminates the poison of saline-alkali via roots. $S$. salsa has a stronger ability of habitat transformation and can provide better habitat for other plants.

\section{Background}

Soil salinization is a serious environmental problem that largely restricts the production of agroforestry [1]. More than $20 \%$ of irrigated soils are affected by saline-alkali stress worldwide and the situation is continuously deteriorating [2]. The area of salinized land is growing at a rate of 1.5 million ha per year. The increase of soluble salt in soil causes a hypertonic condition and hinders water absorption by roots. The substantial accumulation of metal ion in the cytoplasm destroys ionic equilibrium $[3,4]$ The change of $\mathrm{pH}$ leads to acid-base imbalance and damages plant cell membrane structure [5]. These factors seriously impair land utilization. Anthropogenic disturbance and intervention further aggravate soil erosion, exacerbate land desertification, and destructs aquifer resources. Salt-alkali affected soils cause the imbalance between plants and the external environment, decrease plant photosynthetic rate, and disrupt the normal metabolism of plants [6-8]. Saline-alkali stress reduces osmotic potential, causes ion imbalance, inhibits plant growth, and even leads to plant death $[9,10]$. Salinization-induced lack of water and arid climates further affect the resistance to alkalinity and aggravate soil erosion [11].

Hulun Buir Grassland is a famous natural pasture located in Northeast China. However, it is reported that degradation, desertification, and salinization affect 46 million hectares in the Hulun Buir Grassland, accounting for $62.68 \%$ of total area [12]. The increase of salinized land results in decreased production and quality of herbage. Salinization-induced damage causes vegetation degradation, induces more 
severe grassland salinization, and causes low-yield of pastures. Therefore, it is in urgent need of solving soil salinization of the Hulun Buir Grassland.

There are many saline-alkali grassland communities in the Hulun Buir Grassland. These saline-alkali resistant natural plants improve the properties of soil and provide better live conditions for the other plants. They are not only beneficial for ecological restoration, but also the ideal materials for studying salt-alkali stress. Suaeda salsa (S. salsa) and Puccinellia tenuiflora (P. tenuiflora) are two very important saline-alkali tolerant plants and community-building species in the Hulun Buir Grassland. S. salsa is recognized as the first-line warrior to defend salt-alkali stress $[13,14]$. It exhibits high salt tolerance during germination, growth, and reproduction [15]. P. tenuiflora generally grows in degraded grasslands or salinized soils $[16,17]$. It has strong salt-alkali resistance and is known as "pioneer in the saline-alkali grass". It is found that $P$. tenuiflora can growth well in the soil of a pH value higher than 10 and a salt content greater than 5\% [18]. Considering that $S$. salsa and P. tenuiflora can effectively improve the surrounding environment, it is important to explore the response mechanisms of $S$. salsa and $P$. tenuiflora under saline-alkali stress. In the current study, we collected $S$. salsa and $P$. tenuiflora from their communities and determined their metabolic changes, aiming to reveal the differences of their salinealkali responses. Our study may help to seek a way to improve vegetation restoration, increase crop yield, and encourage the sustainable development of agriculture.

\section{Result}

\section{Overview of S. salsa and P. tenuiflora communities}

P. tenuiflora community shows more species diversity and land cover than S. salsa community (Fig. 1). Soils around $S$. salsa community present "leucophylline" and harden into a lump, indicating that $S$. salsa faces more serious saline-alkali stress. According to soil alkalization classification standard (SSC), both the rhizosphere soils of $S$. salsa and $P$. tenuiflora belong to salinization soils (Table 1 ). The alkalization of $S$. salsa rhizosphere soil is significantly higher than $P$. tenuiflora rhizosphere soil and is classified as severe salinization $(\mathrm{pH}>9.0)($ Table 1$)$.

Table 1

The soil indicator around S. salsa and P. tenuiflora.

\begin{tabular}{|c|c|c|c|c|c|c|}
\hline & $\mathrm{pH}$ & $\mathrm{Na}^{+} / \mathrm{K}^{+}$ & $\mathrm{CO}_{3}{ }^{2-}$ & $\mathrm{HCO}_{3}^{-}$ & $\mathrm{Cl}^{-}$ & $\mathrm{SO}_{4}{ }^{2-}$ \\
\hline S1 & $\begin{array}{l}9.74 \pm \\
0.14^{\star \star}\end{array}$ & $\begin{array}{l}32.96 \pm \\
2.34^{\star \star}\end{array}$ & $\begin{array}{l}0.018 \pm \\
0.003\end{array}$ & $\begin{array}{l}0.037 \pm \\
0.009 \star *\end{array}$ & $0.090 \pm .014^{*}$ & $\begin{array}{l}0.20 \\
\pm .021\end{array}$ \\
\hline S2 & $\begin{array}{l}8.53 \pm \\
0.25^{\star \star}\end{array}$ & $\begin{array}{l}21.20 \pm \\
2.62^{\star \star}\end{array}$ & $\begin{array}{l}0.015 \pm \\
0.001\end{array}$ & $\begin{array}{l}0.005 \pm \\
0.001^{* \star}\end{array}$ & $\begin{array}{l}0.037 \pm \\
0.009^{*}\end{array}$ & $\begin{array}{l}0.09 \\
\pm .011\end{array}$ \\
\hline
\end{tabular}


In order to explore the differences of saline-alkali resistance between $S$. salsa and $P$. tenuiflora, GC-MS was used to detect the amounts of metabolites related to the response of saline-alkali stress. $S$. salsa and P. tenuiflora were clearly separated by means of PC1 (22.9\%) and PC2 (23.0\%) of OPLS-DA, a supervised method which could classify observations into the group with largest predicted indicator variable (Fig. 2. a). A total of 68 significantly different metabolites between $S$. salsa and $P$. tenuiflora were obtained according to their variable importance in the projection (VIP, VIP $>1)$ and $p$-values $(p<0.05)$. These significantly different metabolites could be classified to 9 sugars, 13 amino acids, 8 alcohols, 34 acids, and 4 other compounds (Table S1). The calculation of principal component $Q$ value showed that sugars were obviously accumulated in P. tenuiflora (Fig. 2b) while other primary metabolites, i.e., amino acids, alcohols, and acids were all significantly higher in $S$. salsa than $P$. tenuiflora (Fig. 2c-2e). The distributions of these primary metabolites were also different in different parts (root, stem, and leaf) of plants. For instance, the root of $P$. tenuiflora had the lowest $Q$ value of sugars while the leaf of $P$. tenuiflora had the highest Q values of sugars (Fig. 2b). On the contrast, the root of $P$. tenuiflora had the highest $Q$ values of amino acids, alcohols, and acids while the leaf of $P$. tenuiflora had the lowest $Q$ values (Fig. 2c-2e).

The distributions of these primary metabolisms were further analyzed. The sugars showed that among 9 significantly different sugars, only two kinds of 6-carbon sugars, sorbose and fucose, were enriched in $S$. salsa (Fig. 3). Other 7 kinds of sugars were all highly accumulated in P. tenuiflora, including 6-carbon sugars tagatose, D-talose, fructose, and D-galactose, 12-carbon sugars sucrose and maltotriitol, and 18carbon sugar melezitose (Fig. 3). These sugars not only provide energy in plants, but also play a key role in resisting saline-alkali stress.

Different from sugars, detailed analyses of differentially expressed amino acids showed that most kinds of amino acids were remarkably accumulated in S. salsa (Fig. 4). Only isoleucine, norlecucine, and aspartic acid were accumulated at higher levels in P. tenutiflora, with isoleucine largely accumulated in the leaf and norlecucine as well as aspartic acid largely accumulated in the root (Fig. 4). Other amino acids were discovered to be highly accumulated in $S$. salsa, especially in the aboveground part of $S$. salsa (Fig. 4). These amino acids play an important role on osmoregulation under saline-alkali stress.

Similar as amino acids, the majority of differentially expressed alcohols showed high abundances in $S$. salsa (Fig. 5). And these alcohols were mainly accumulated in the aboveground part of $S$. salsa. Two other alcohols, cuminic alcohol and xylitol, were found to be accumulated in P. tenutiflora (Fig. 5). Cuminic alcohol was enriched in the root of $P$. tenutiflora while xylitol was enriched in the leaf.

Acids accounted for a large proportion of significantly different metabolites (Table 2). Differentially expressed acids were grouped into phenolic compounds, organic acids, and volatile compounds, artificially. Detailed investigation of organ-specific expression of acids showed that acids were largely accumulated in the aboveground part of $S$. salsa and the root of $P$. tenuiflora (Table 2). 
Table 2

Significantly different acids in root, stem, and left of $S$. salsa and P. tenuiflora.

\begin{tabular}{|c|c|c|c|c|c|c|c|}
\hline \multirow[t]{2}{*}{ Acids } & & \multicolumn{3}{|l|}{ S. salsa } & \multicolumn{3}{|c|}{ P. tenuiflora } \\
\hline & & root & stem & Leaf & root & stem & Leaf \\
\hline \multirow[t]{7}{*}{$\begin{array}{l}\text { phenolic } \\
\text { compounds }\end{array}$} & gallic acid & $\begin{array}{l}27.73 \\
\pm 3.0^{a}\end{array}$ & $\begin{array}{l}54.35 \pm \\
5.97^{\mathrm{a}}\end{array}$ & $\begin{array}{l}76.9 \pm \\
12.26^{a}\end{array}$ & $\begin{array}{l}22.58 \pm \\
7.05^{a}\end{array}$ & $\begin{array}{l}8.26 \pm \\
2.85^{b}\end{array}$ & $\begin{array}{l}10.92 \pm \\
2.74^{b}\end{array}$ \\
\hline & $\begin{array}{l}\text { protocatechuic } \\
\text { acid }\end{array}$ & $\begin{array}{l}5.2 \pm \\
1.72^{a}\end{array}$ & $\begin{array}{l}4.86 \pm \\
1.98^{a}\end{array}$ & $\begin{array}{l}8.41 \pm \\
2.23^{a}\end{array}$ & $\begin{array}{l}5.12 \pm \\
1.16^{a}\end{array}$ & $\begin{array}{l}0.95 \pm \\
0.3^{b}\end{array}$ & $\begin{array}{l}0.77 \pm \\
0.34^{b}\end{array}$ \\
\hline & catechol & $\begin{array}{l}0.419 \\
\pm 0.26^{a}\end{array}$ & $\begin{array}{l}1.87 \pm \\
0.82^{a}\end{array}$ & $\begin{array}{l}1.42 \pm \\
0.91^{a}\end{array}$ & $0^{b}$ & $\begin{array}{l}0.29 \pm \\
0.09^{b}\end{array}$ & $\begin{array}{l}0.24 \pm \\
0.01^{b}\end{array}$ \\
\hline & epigallocatechin & $\begin{array}{l}1.30 \pm \\
0.32^{a}\end{array}$ & $\begin{array}{l}2.34 \pm \\
0.44^{a}\end{array}$ & $\begin{array}{l}4.92 \pm \\
1.08^{a}\end{array}$ & $\begin{array}{l}1.01 \pm \\
0.19^{a}\end{array}$ & $\begin{array}{l}0.22 \pm \\
0.04^{b}\end{array}$ & $0^{b}$ \\
\hline & vanillic acid & $\begin{array}{l}2.01 \pm \\
0.69^{a}\end{array}$ & $\begin{array}{l}4.47 \pm \\
1.70^{a}\end{array}$ & $\begin{array}{l}7.11 \pm \\
1.57^{a}\end{array}$ & $\begin{array}{l}1.73^{ \pm} \\
0.35^{a}\end{array}$ & $\begin{array}{l}0.48 \pm \\
0.12^{b}\end{array}$ & $\begin{array}{l}0.48 \pm \\
0.09^{b}\end{array}$ \\
\hline & vinylphenol & $\begin{array}{l}5.88 \pm \\
1.46^{a}\end{array}$ & $\begin{array}{l}7.69 \pm \\
1.29^{a}\end{array}$ & $\begin{array}{l}7.55 \pm \\
0.73^{a}\end{array}$ & $\begin{array}{l}6.15 \pm \\
1.66^{a}\end{array}$ & $\begin{array}{l}1.9 \pm \\
0.93^{b}\end{array}$ & $\begin{array}{l}1.77 \pm \\
0.66^{b}\end{array}$ \\
\hline & guaiacol & $\begin{array}{l}0.96 \pm \\
0.43^{a}\end{array}$ & $\begin{array}{l}1.78 \pm \\
0.43^{a}\end{array}$ & $\begin{array}{l}2.23 \pm \\
0.62^{a}\end{array}$ & $\begin{array}{l}1.03 \pm \\
0.34^{\mathrm{a}}\end{array}$ & $\begin{array}{l}0.24 \pm \\
0.05^{b}\end{array}$ & $\begin{array}{l}0.22 \pm \\
0.04^{b}\end{array}$ \\
\hline \multirow[t]{7}{*}{$\begin{array}{l}\text { organic } \\
\text { acids }\end{array}$} & citraconic acid & $\begin{array}{l}8.21 \pm \\
1.22^{a}\end{array}$ & $\begin{array}{l}10.85 \pm \\
2.79 a^{a}\end{array}$ & $\begin{array}{l}7.97 \pm \\
0.7^{a}\end{array}$ & $\begin{array}{l}4.49 \pm \\
1.8^{\mathrm{b}}\end{array}$ & $\begin{array}{l}1.43 \pm \\
0.81^{b}\end{array}$ & $\begin{array}{l}1 \pm 0.48 \\
b\end{array}$ \\
\hline & malonic acid & $\begin{array}{l}34.97 \\
\pm 10.72 \\
a\end{array}$ & $\begin{array}{l}43.78 \pm \\
16.69^{a}\end{array}$ & $\begin{array}{l}75.82 \pm \\
22.5^{a}\end{array}$ & $\begin{array}{l}30.84 \pm \\
8.08^{a}\end{array}$ & $\begin{array}{l}15.04 \\
\pm 5.2^{\mathrm{b}}\end{array}$ & $\begin{array}{l}15.68 \pm \\
2.08^{b}\end{array}$ \\
\hline & succinic acid & $\begin{array}{l}44.36 \\
\pm 12.5^{a}\end{array}$ & $\begin{array}{l}144.7 \pm \\
17.51^{\mathrm{a}}\end{array}$ & $\begin{array}{l}51.73 \pm \\
17.3^{a}\end{array}$ & $\begin{array}{l}47.51 \pm \\
18.11^{a}\end{array}$ & $\begin{array}{l}15.77 \\
\pm 2.66 \\
b\end{array}$ & $\begin{array}{l}14.59 \\
\pm 4\end{array}$ \\
\hline & tartaric acid & $\begin{array}{l}1.02 \pm \\
0.37^{a}\end{array}$ & $\begin{array}{l}2.43 \pm \\
1.26^{a}\end{array}$ & $\begin{array}{l}1.75 \pm \\
0.58^{a}\end{array}$ & $\begin{array}{l}0.98 \pm \\
0.35^{a}\end{array}$ & $0^{b}$ & $\begin{array}{l}0.33^{ \pm} \\
0.12^{b}\end{array}$ \\
\hline & itaconic acid & $\begin{array}{l}20.76 \\
\pm 4.65^{a}\end{array}$ & $\begin{array}{l}39.92 \pm \\
8.93^{a}\end{array}$ & $\begin{array}{l}28.12 \pm \\
8.73^{a}\end{array}$ & $\begin{array}{l}19.04 \pm \\
6.52^{a}\end{array}$ & $\begin{array}{l}3.38 \pm \\
1.42^{b}\end{array}$ & $\begin{array}{l}4.44 \pm \\
1.63^{b}\end{array}$ \\
\hline & pelargonic acid & $\begin{array}{l}0.52 \pm \\
0.17^{\mathrm{a}}\end{array}$ & $\begin{array}{l}0.88 \pm \\
0.16^{a}\end{array}$ & $\begin{array}{l}1.91 \pm \\
0.82^{a}\end{array}$ & $\begin{array}{l}0.91 \pm \\
0.23^{a}\end{array}$ & $\begin{array}{l}0.31 \pm \\
0.1^{\mathrm{a}}\end{array}$ & $\begin{array}{l}0.19 \pm \\
0.08^{b}\end{array}$ \\
\hline & glycolic acid & $\begin{array}{l}17.41 \\
\pm 6.24\end{array}$ & $\begin{array}{l}40.57 \pm \\
11.34^{a}\end{array}$ & $\begin{array}{l}55.77 \pm \\
8.35^{a}\end{array}$ & $\begin{array}{l}19.86 \pm \\
7.744^{a}\end{array}$ & $\begin{array}{l}6.31 \pm \\
2.07^{b}\end{array}$ & $\begin{array}{l}10.11 \pm \\
2.02^{b}\end{array}$ \\
\hline
\end{tabular}




\begin{tabular}{|c|c|c|c|c|c|c|c|}
\hline \multirow[t]{2}{*}{ Acids } & & \multicolumn{3}{|l|}{ S. salsa } & \multicolumn{3}{|c|}{ P. tenuiflora } \\
\hline & & root & stem & Leaf & root & stem & Leaf \\
\hline & $\begin{array}{l}\text { 3-methylglutaric } \\
\text { acid }\end{array}$ & $\begin{array}{l}1.46 \pm \\
0.59^{a}\end{array}$ & $0^{a}$ & $\begin{array}{l}0.9 \pm \\
0.58^{a}\end{array}$ & $0^{b}$ & $0^{a}$ & $0^{b}$ \\
\hline & $\begin{array}{l}\text { aminooxyacetic } \\
\text { acid }\end{array}$ & $\begin{array}{l}11.64 \\
\pm 4.1^{\mathrm{a}}\end{array}$ & $\begin{array}{l}13.44 \pm \\
3.72^{a}\end{array}$ & $\begin{array}{l}18.03 \pm \\
6.91^{\mathrm{a}}\end{array}$ & $\begin{array}{l}8.44 \pm \\
3.7^{\mathrm{a}}\end{array}$ & $\begin{array}{l}0.79 \pm \\
0.36^{\mathrm{b}}\end{array}$ & $\begin{array}{l}0.63 \pm \\
0.27^{b}\end{array}$ \\
\hline & oxalic acid & $\begin{array}{l}2.58 \pm \\
0.97^{a}\end{array}$ & $\begin{array}{l}3.63 \pm \\
0.6^{a}\end{array}$ & $\begin{array}{l}4.01 \pm \\
0.85^{a}\end{array}$ & $\begin{array}{l}3 \pm 0.49 \\
\mathrm{a}\end{array}$ & $\begin{array}{l}0.81 \pm \\
0.25^{b}\end{array}$ & $\begin{array}{l}1.15 \pm \\
0.2^{b}\end{array}$ \\
\hline & L-gulonic acid & $\begin{array}{l}2.5 \pm \\
1.1^{b}\end{array}$ & $\begin{array}{l}3.84 \pm \\
1.15^{a}\end{array}$ & $\begin{array}{l}2.01 \pm \\
0.39^{b}\end{array}$ & $\begin{array}{l}12.86 \pm \\
5.38^{a}\end{array}$ & $\begin{array}{l}10.44 \\
\pm 3.03 \\
a\end{array}$ & $\begin{array}{l}10.18 \\
\pm 2.14\end{array}$ \\
\hline & cumic acid & $\begin{array}{l}4.15 \pm \\
1.26^{a}\end{array}$ & $\begin{array}{l}6.76 \pm \\
2.23^{a}\end{array}$ & $\begin{array}{l}9.27 \pm \\
2.82^{a}\end{array}$ & $\begin{array}{l}5.43 \pm \\
1.72^{a}\end{array}$ & $\begin{array}{l}1.43^{ \pm} \\
0.58^{b}\end{array}$ & $\begin{array}{l}0.63 \pm \\
0.18^{b}\end{array}$ \\
\hline & palmitic acid & $\begin{array}{l}295.15 \\
\pm 86.1^{\mathrm{a}}\end{array}$ & $\begin{array}{l}401.49 \\
\pm \\
42.39^{a}\end{array}$ & $\begin{array}{l}577.35 \\
\pm \\
140.8^{a}\end{array}$ & $\begin{array}{l}508.25 \\
\pm \\
214.83^{a}\end{array}$ & $\begin{array}{l}99.91 \\
\pm \\
31.2^{\mathrm{b}}\end{array}$ & $\begin{array}{l}76.59 \pm \\
18.34^{\mathrm{b}}\end{array}$ \\
\hline \multirow[t]{8}{*}{$\begin{array}{l}\text { volatile } \\
\text { compounds }\end{array}$} & methylfumarate & $\begin{array}{l}0.94 \pm \\
0.29^{a}\end{array}$ & $\begin{array}{l}1.83^{ \pm} \\
0.36^{a}\end{array}$ & $\begin{array}{l}1.46 \pm \\
0.24^{a}\end{array}$ & $\begin{array}{l}0.71 \pm \\
0.3^{a}\end{array}$ & $\begin{array}{l}0.16 \pm \\
0.06^{b}\end{array}$ & $\begin{array}{l}0.16 \pm \\
0.04^{b}\end{array}$ \\
\hline & hydroxybutyrate & $0^{b}$ & $0^{b}$ & $\begin{array}{l}0.32 \pm \\
0.08^{a}\end{array}$ & $\begin{array}{l}0.35 \pm \\
0.08^{a}\end{array}$ & $\begin{array}{l}0.16 \pm \\
0.02^{a}\end{array}$ & $\begin{array}{l}0.31 \pm \\
0.12^{a}\end{array}$ \\
\hline & gluconic lactone & $\begin{array}{l}2.89 \pm \\
0.86^{a}\end{array}$ & $\begin{array}{l}2.46 \pm \\
0.85^{a}\end{array}$ & $\begin{array}{l}0.98 \pm \\
0.19^{a}\end{array}$ & $0^{b}$ & $0^{b}$ & $0^{b}$ \\
\hline & $\begin{array}{l}\text { methyl } \\
\text { hexadecanoate }\end{array}$ & $\begin{array}{l}0.33^{ \pm} \\
0.07^{a}\end{array}$ & $\begin{array}{l}0.52 \pm \\
0.19^{a}\end{array}$ & $\begin{array}{l}0.92 \pm \\
0.43^{a}\end{array}$ & $0^{b}$ & $0^{b}$ & $\begin{array}{l}0.11 \pm \\
0.01^{\mathrm{b}}\end{array}$ \\
\hline & dioctyl phthalate & $\begin{array}{l}9.13^{ \pm} \\
3.25^{a}\end{array}$ & $\begin{array}{l}13.3 \pm \\
2.6^{a}\end{array}$ & $\begin{array}{l}20.1 \pm \\
6.35^{a}\end{array}$ & $\begin{array}{l}8.92^{ \pm} \\
1.62^{a}\end{array}$ & $\begin{array}{l}1.39 \pm \\
0.5^{\mathrm{b}}\end{array}$ & $\begin{array}{l}1.24 \pm \\
0.24 \mathrm{~b}\end{array}$ \\
\hline & $\begin{array}{l}\text { methyl } \\
\text { heptadecanoate }\end{array}$ & $\begin{array}{l}3.76 \pm \\
0.59^{a}\end{array}$ & $\begin{array}{l}8.3 \pm \\
1.01^{\mathrm{a}}\end{array}$ & $\begin{array}{l}4.16 \pm \\
0.52^{a}\end{array}$ & $\begin{array}{l}1.87 \pm \\
0.77^{b}\end{array}$ & $\begin{array}{l}0.69 \pm \\
0.28^{b}\end{array}$ & $\begin{array}{l}0.44 \pm \\
0.09 \mathrm{~b}\end{array}$ \\
\hline & $\begin{array}{l}\text { nonanoic acid } \\
\text { methyl ester }\end{array}$ & $\begin{array}{l}78.7 \pm \\
17.98^{a}\end{array}$ & $\begin{array}{l}105.39 \\
\pm \\
22.62^{a}\end{array}$ & $\begin{array}{l}149.24 \\
\pm \\
28.53^{a}\end{array}$ & $\begin{array}{l}113.66 \\
\pm 33.08 \text { a }\end{array}$ & $\begin{array}{l}23.24 \\
\pm \\
6.98^{b}\end{array}$ & $\begin{array}{l}19.38 \pm \\
4.56^{b}\end{array}$ \\
\hline & methyl octanoate & $\begin{array}{l}44.05 \\
\pm 6.29 \text { a }\end{array}$ & $\begin{array}{l}58.75 \pm \\
12.81^{a}\end{array}$ & $\begin{array}{l}91.8 \pm \\
16.65^{\mathrm{a}}\end{array}$ & $\begin{array}{l}62.31 \pm \\
18.85^{a}\end{array}$ & $\begin{array}{l}14.03 \\
\pm \\
3.21^{b}\end{array}$ & $\begin{array}{l}10.16 \pm \\
3.31^{\mathrm{b}}\end{array}$ \\
\hline
\end{tabular}

The relative contents of acids are summarized from 6 biological replicates and presented as the mean \pm standard error of 6 biological replicates. Different letters indicate significant differences among treatments $(p<0.05)$. 


\begin{tabular}{|c|c|c|c|c|c|c|c|}
\hline \multirow{2}{*}{\multicolumn{2}{|c|}{ Acids }} & \multicolumn{3}{|c|}{ S. salsa } & \multicolumn{3}{|c|}{ P. tenuiflora } \\
\hline & & root & stem & Leaf & root & stem & Leaf \\
\hline \multicolumn{2}{|r|}{ L-gulonolactone } & $0^{a}$ & $0^{b}$ & $0^{b}$ & $0^{a}$ & $\begin{array}{l}1.61 \pm \\
0.04^{\mathrm{a}}\end{array}$ & $\begin{array}{l}8.46 \pm \\
3.61^{\mathrm{a}}\end{array}$ \\
\hline \multicolumn{2}{|r|}{ phenylacetic acid } & $0^{b}$ & $\begin{array}{l}0.64 \pm \\
0.22^{a}\end{array}$ & $\begin{array}{l}0.64 \pm \\
0.2^{a}\end{array}$ & $\begin{array}{l}0.33 \pm \\
0.18^{a}\end{array}$ & $0^{b}$ & $0^{b}$ \\
\hline \multicolumn{2}{|r|}{$\begin{array}{l}\text { hydroxymandelic } \\
\text { acid }\end{array}$} & $\begin{array}{l}10.65 \\
\pm 2.1^{\mathrm{a}}\end{array}$ & $\begin{array}{l}8.9 \pm \\
0.96^{a}\end{array}$ & $\begin{array}{l}13.56 \pm \\
3.56^{a}\end{array}$ & $\begin{array}{l}11.85 \pm \\
4.5^{\mathrm{a}}\end{array}$ & $\begin{array}{l}3.24 \pm \\
0.83^{a}\end{array}$ & $\begin{array}{l}2.1 \pm \\
0.5^{b}\end{array}$ \\
\hline & $\begin{array}{l}\text { 5-hydroxyindole-2- } \\
\text { carboxylic acid }\end{array}$ & $\begin{array}{l}0.73^{ \pm} \\
0.32^{a}\end{array}$ & $\begin{array}{l}1.57 \pm \\
0.88^{a}\end{array}$ & $\begin{array}{l}1.89 \pm \\
0.54^{a}\end{array}$ & $0^{a}$ & $\begin{array}{l}0.22 \pm \\
0.04^{b}\end{array}$ & $\begin{array}{l}0.36 \pm \\
0.09^{b}\end{array}$ \\
\hline & $\begin{array}{l}\text { 5-hydroxyindole-3- } \\
\text { acetic acid }\end{array}$ & $\begin{array}{l}1.41 \pm \\
0.82^{a}\end{array}$ & $\begin{array}{l}3.17 \pm \\
0.68^{a}\end{array}$ & $\begin{array}{l}2.39 \pm \\
0.37^{a}\end{array}$ & $\begin{array}{l}1.37 \pm \\
0.39 a\end{array}$ & $\begin{array}{l}0.27 \pm \\
0.13^{b}\end{array}$ & $0^{b}$ \\
\hline $\begin{array}{l}\text { The re } \\
\text { mean } \\
\text { amon }\end{array}$ & $\begin{array}{l}\text { tents of acids are } \\
\text { d error of } 6 \text { biologi } \\
\text { nts }(p<0.05)\end{array}$ & $\begin{array}{l}\text { nmariz } \\
\text { replica }\end{array}$ & $\begin{array}{l}\text { om } 6 \\
\text { Differ }\end{array}$ & $\begin{array}{l}\text { gical rep } \\
\text { tters inc }\end{array}$ & $\begin{array}{l}\text { tes anc } \\
\text { te signif }\end{array}$ & $\begin{array}{l}\text { ented } \\
\text { differ }\end{array}$ & $\begin{array}{l}\text { the } \\
\text { ses }\end{array}$ \\
\hline
\end{tabular}

\section{The responses of phenolic compounds to saline-alkali stress}

Phenolic compounds from phenylalanine metabolism are important for plant development and defense and play an essential role in saline-alkali stress. To explore the involvement of phenolic compounds in saline-alkali stress, HPLC-qTOF-MS was performed, and the accumulation of a total of 34 phenolic compounds were measured. 20 phenolic compounds were found to be accumulated in $S$. salsa and $P$. tenuiflora, and 8 phenolic compounds were identified to be significant differently expressed (VIP $>1$ and $p<0.05$ ) by OPLS-DA (Figure S1). These 8 significantly different phenolic compounds could be divided into $2 \mathrm{C} 6 \mathrm{C} 1$-compounds (protocatechuic acid and gallic acid), $2 \mathrm{C} 6 \mathrm{C} 3-c o m p o u n d s$ (chlorogenic acid, $\mathrm{p}$ hydroxycinnamic acid), and 4 C6C3C6-compounds (luteolin, quercetin, myricitrin, and petunidin), according to their carbon skeleton (Fig. 6). C6C1-compounds were found to be notably accumulated in $S$. salsa, especially the aboveground part of $S$. salsa while C6C3-compounds and C6C3C6-compounds were identified to be mainly enriched in $P$. tenuiflora (Fig. 6).

\section{Discussion}

Saline-alkali tolerant plants show excellent potentials for preventing soil salinization, improving the ecological environment, and providing live conditions for the other plants that have lower tolerance to saline-alkali stress [2]. Emerging studies have focused on biological responses of saline-alkali tolerant plant, aiming to decipher saline-alkali tolerant mechanisms. For example, Chenopodium quinoa Wild. has been used to investigate the genotype-dependent variability in salinity responses from morphological, 
physiological, cellular, and molecular aspects [21]. However, these plant tolerance or defense studies are mainly conducted by indoor control $[16,22,23]$. The application of indoor control cannot fully reflect the real responses of plants to saline-alkali stress as plants survive from saline-alkali soil usually undergo a long-term adaptation and evolution with habitat. In the current study, we measured the expressions of metabolites in S. salsa and P. tenuiflora, which survive in saline-alkali soil, using GC-MS and LC-qTOF-MS and demonstrated diverse metabolites with varied intensities in $S$. salsa and $P$. tenuiflora.

Many sugars have been identified as regulatory components in the control of glycolytic flux in a variety of stress survival strategies [19]. They not only act as readily available energy source for plant growth under stress, but function as osmoprotectants to maintain osmotic balance and stabilize macromolecules [24]. Soluble sugars provide adaptive buffer for plants under saline-alkali stress and play an important role in regulating osmotic pressure $[25,26]$. In our studies, many soluble sugars, including sorbose, fucose, and D-talose, are highly expressed. They have the ability to balance osmotic pressure and protect the biological structures of plants from desiccation damage $[27,28]$. Notably, many metabolites in glycolysis/gluconeogenesis pathways were found to be significantly accumulated in $P$. tenuiflora, indicating that the production of downstream products through metabolic flux from these pathways is essential for salt-alkali tolerance. Therefore, it is likely that $P$. tenuiflora can regulate the central metabolism by effectively utilizing carbon, accumulating carbon assimilation production, and providing more material and energy to promote the tolerance against salt-alkali stress.

Nitrogen metabolism has been reported to be strongly interconnected with carbon metabolism [29]. Sufficient carbon skeleton source and energy supply are important for the assimilation of nitrogen and the synthesis of amino acids [30]. Plants respond to high salinity by limiting protein synthesis, promoting protein degradation, and changing amino acid compositions [31, 32]. Here, significant enrichment of amino acids was discovered in S. salsa. Therefore, we speculate that $S$. salsa uses different salt-alkali response strategy as $P$. tenuiflora. In $P$. tenuiflora, a large portion of carbon influx to sugars while only amino acids isoleucine, norleucine, and aspartatic acid were highly accumulated (Figure. 3a). Isoleucine and norleucine can improve salt resistance and maintain the metabolic and osmotic homeostasis under stress [24]. Aspartic acid can act as an immediate donor of amino groups for the synthesis of other amino acids [30]. Many other amino acids, including glutamine, proline, alanine, tyrosine, ornithine, and 3hydroxynorvaline, were identified to be significantly accumulated in $S$. salsa. Glutamine has an elevated nitrogen-to-carbon ratio and can use limited carbon skeletons to response to environmental stresses [33, 34]. Proline is generally considered as an osmotic regulator and an active oxygen scavenger in response to high salinity [35]. Like molecular chaperone, proline can form a protective film [36]. Proline are mainly produced by glutamate synthesis pathway and ornithine synthesis pathway [36]. Activation of ornithine synthesis pathway also plays a vital role in improving plant salt tolerance. Noteworthy, aminobutyric acid, which is involved in various stress response and defense mechanisms, is also considerably accumulated in $S$. salsa. Aminobutyric acid can maintain carbon and nitrogen balance, protect plants from oxidative stress, and regulate the $\mathrm{pH}$ value of cytoplasmic. These differentially regulated amino acids help $S$. salsa to survive under saline-alkali stress. 
Alcohols help to reserve available water in plants and thus are considered as essential osmotic regulators. In our current study, accumulated alcohols in the aboveground part of $S$. salsa were discovered (Fig. 5). These alcohols benefit the maintenance of osmotic pressure balance in cytoplasm and contribute to the regulation of water loss [37]. In addition, alcohols work as natural scavengers of salinity-induced reactive oxygen species and protect the biomolecules against oxidative damage [38].

The roles of soluble sugars, alcohols, and amino acids in resisting saline-alkali stress have been well acknowledged. Our current study revealed that a large proportion of differently expressed metabolizes were acids, implying the potential involvement of acids in plant protection. Acids can enhance plant stress resistance and stabilize intracellular $\mathrm{pH}$ [39]. We found that many acids were accumulated in the aboveground part of $S$. salsa. These acids may help to maintain ionic balance by neutralizing alkali and excess toxic ions. They can also affect the fluidity and hydrophobicity of cell membrane, which is crucial for cell membrane activity maintenance and saline-alkali stress defense [40]. Notably, some acids, such as nonanoic acid methyl ester, methyl hexadecanoate, and phenylacetic acid, have obvious flavors and are volatile. Secretion of these acids may affect the surrounding environment and influence soil composition (Table 2). Volatile substances are also communication factors that contribute to plant defense and reproduction [41]. Therefore, these volatile substances may improve soil properties via signal transmission and communication. The pioneer role of $S$. salsa may be partially attributed to the successful secretion of these allelopathic compounds under saline-alkali stress.

Our GC-MS results showed that gallic acid, vanillic acid, protocatechuic acid, and catechol, acids subordinated to phenolic compounds, were obviously accumulated. These compounds are secondary metabolites that originate from phenylalanine metabolism [20,42, 43]. Gallic acid and protocatechuic acid are the precursors of tannin, which can affect plant thickness and reduce water evaporation [19]. Moreover, a larger number of other phenolic compounds were investigated. Bioactive phenolic compounds are important biofactories of plants under stress $[44,45]$. These compounds are mainly divided into the benzoid acid derivatives with $\mathrm{C} 6 \mathrm{C} 1$ carbon skeleton ( $66 \mathrm{C} 1$-compounds), the hydroxycinnamic acid derivatives with $\mathrm{C} 6 \mathrm{C} 3$ carbon skeleton (C6C3-compounds), and the flavonoids with C6C3C6 carbon skeleton (C6C3C6-compounds). Our results demonstrated the enrichment of C6C1compounds in S. salsa as well as enrichment of $\mathrm{C6C3}$ - and $\mathrm{C6C3C6-compounds} \mathrm{in} \mathrm{P.} \mathrm{tenuiflora} \mathrm{(Figure.}$ 5). C6C1-compounds, usually induced by biotic elicitors, are signaling molecules that defense stress. C6C3C6-compounds are flavonoids that can directly enhance the chemical defense of plants and help

plants adapting to their environments [46]. Significantly accumulation of phenolic compounds in $S$. salsa and $P$. tenuiflora may thus benefit their saline-alkali tolerance.

\section{Conclusion}

In short, our result showed that $S$. salsa resists the toxicity of saline-alkali stress using aboveground organs and $P$. tenuiflora eliminates the poison of saline-alkali via roots. $S$. salsa has stronger ability of habitat transformation and is more tolerant of saline-alkali than $P$. tenuiflora. The analyses of different metabolites of $S$. salsa and $P$. tenuiflora provide an important theoretical basis for understanding the 
mechanisms of saline-alkali tolerance and may help to deepen the knowledge of plant metabolism regulation under stress.

\section{Materials And Methods}

\section{Materials collected}

S. salsa and $P$. tenuiflora were selected from S. salsa and $P$. tenuiflora communities of the open area of the Hulun Buir Grassland in China (115 $\left.31^{\prime} 00^{\prime \prime}-121^{\circ} 34^{\prime} 30^{\prime \prime}, 47^{\circ} 20^{\prime} 00^{\prime \prime}-50^{\circ} 50^{\prime} 30^{\prime \prime}\right)$. Samples were collected from three different plots with similar transitional communities from $S$. salsa to $P$. tenuiflora. Distances between sample plots were greater than 500 kilometers. 3 plants were selected from each community with 6 repeats and stored in drikold. Soil samples derived from the habitats of $S$. salsa and $P$. tenuiflora were collected along the vertical length of $20 \mathrm{~cm}$ depth for characterizing salinization with 3-6 repeats.

\section{The detected of soil salinity and alkalinity}

Soil samples were dried at room temperature for 2 weeks, pulverized, and sieved through a $2 \mathrm{~mm}$ mesh sieve. Saturation paste extract was prepared for soil detection. Soil samples were digested with HF$\mathrm{HClO}_{4}-\mathrm{HNO}_{3}$ method. Contents were determined by flame photometry (410, Corning, Halstead, England), colorimetry (Double beam spectrophotometer, UV-140-02, Shimadzu), and titration method (carbonates and bicarbonates, and chlorides). The $\mathrm{pH}$ of soil was measured with a glass electrode $\mathrm{pH}$ meter (pHM2000, Eyela, Rikakikai Co., Tokyo, Japan) in the saturation paste titration.

\section{GC-MS analysis}

GC-MS was performed as previously described [19]. $60 \mathrm{mg}$ samples were mixed with $360 \mu \mathrm{L}$ cold methanol and $40 \mu \mathrm{L}$ internal standards. Samples were homogenized (Tissuelyser-192, Shanghai, China), ultrasonicated for $30 \mathrm{~min}$, mixed with $200 \mu \mathrm{L}$ chloroform and $400 \mu \mathrm{L}$ water, and centrifuged at 10,000 g for $10 \mathrm{~min}$ at $4^{\circ} \mathrm{C}$. Finally, $400 \mu \mathrm{L}$ supernatant was transferred to a glass sampling vial for vacuum-dry at room temperature. The residue was derivatized using a two-step procedure. First, $80 \mu \mathrm{L}$ methoxyamine (15 mg Ml-1 in pyridine) was added to the vial, and kept at $37^{\circ} \mathrm{C}$ for 90 min followed by $80 \mu \mathrm{L}$ BSTFA ( $1 \%$ TMCS) and $20 \mu \mathrm{L} \mathrm{n}$-hexane at $70^{\circ} \mathrm{C}$ for $60 \mathrm{~min}$. After derivatization, $1 \mu \mathrm{L}$ solution was injected into the Agilent 7890A-5975C GC-MS system (Agilent Corporation, USA) with a split ratio of 30 to 1. Separation was carried out on a non-polar DB-5 capillary column (30 m × $250 \mu \mathrm{m}$ I.D., J\&W Scientific, Folsom, CA $)$ with high purity helium as the carrier gas at a constant flow rate of $1.0 \mathrm{~mL} / \mathrm{min}$. The temperatures of injection and ion source were set to $260^{\circ} \mathrm{C}$ and $230^{\circ} \mathrm{C}$, respectively. Electron impact ionization $(-70 \mathrm{eV})$ at full scan mode (m/z $30-600)$ was used, with an acquisition rate of 20 spectrum/s in the MS setting. QC sample was prepared by mixing aliquots of tissues samples to be a pooled sample and analyzed using the same method with the analytic samples.

Acquired MS data were analyzed by Chroma TOF software (v 4.34, LECO, St Joseph, MI). Briefly, after alignment with Statistic Compare component, the CSV file was obtained with three-dimension data sets 
including sample information, retention time, and peak intensities. The internal standard was used for data quality control (reproducibility). Internal standards and any known pseudo positive peaks, such as peaks caused by noise, column bleed, and BSTFA derivatization procedure, were removed from the data set. The data set was normalized using the sum intensity of the peaks in each sample.

\section{Phenolic compound detection}

Phenolic compound detection was performed as previously described [20]. After treatment with liquid nitrogen, $1.0 \mathrm{~g}$ pulverized sample was dissolved in $20 \mathrm{~mL}$ methanol for extraction and ultrasonicated at low-frequency for $40 \mathrm{~min}$. The simple solution was centrifuged for $10 \mathrm{~min}$ at 8,000 rpm. The analysis was performed by Waters ACQUITY UPLC system (Waters, Japan) coupled to a quadrupole time-of-flight (qTOF) mass spectrometer (XEVO G2 QTOF, Waters). The chromatographic conditions were: A\%: 0.05\% formic acid-water; B\%: 0.05\% formic acid-acetonitrile; m/z: 120-1200; positive scan mode; chromatographic columns: ACQUIT UPLC-BEH C18 Column $(1.7 \mathrm{~mm}, 2.1 \mathrm{~mm} \times 50 \mathrm{~mm})$. Leu-Enkephalin was used as the internal standard.

Statistical analysis

Data sets obtained from GC-MS and LC-qTOF-MS were imported into SIMCA-P14.1 software package (Umetrics, Umeå, Sweden), separately. After mean centering and unit variance scaling, orthogonal partial least-squares discrimination analysis (OPLS-DA) was carried out to visualize metabolic alterations among experimental groups. Differentially expressed compounds were selected by comparing compounds in the treated group with the control group using the multivariate statistical method. Metabolites with both multivariate and univariate statistical significances (VIP $>1.0$ and $p<0.05$ ) were screened. Default 7-round cross-validation was applied with $1 / 7$ of the samples being excluded from the mathematical model in each round to avoid overfitting.

Data were log2 transformed to improve normality and Min-Max Normalization was performed. Data were subjected to hierarchical clustering analysis by R software to study the variations of $S$. salsa and $P$. tenuiflora. Significantly different metabolites were screened by SIMICA14.1. The score of principal component Q was calculated using Statistical software SPSS version 21.0 software (Chicago, IL, USA). Heat maps, histograms, and pathway maps were drawn with R-3.2 language software, GraphPad Prism8, and Visor, respectively.

\section{Abbreviations}

Suaeda salsa: S. salsa; Puccinellia tenuiflora: P. tenuiflora; Discriminant analysis by orthogonal partial least square: OPLS-DA; soil alkalization classification standard: SSC.

\section{Declarations}

\section{Ethics approval and consent to participate}


Not applicable.

\section{Consent for publication}

Not applicable

\section{Availability of data and materials}

All data generated or analyzed during this study are included in this published article and its supplementary information files.

\section{Competing interests}

The authors declare no competing financial interests.

\section{Funding}

This work was supported by the Research Initiation Funds for Nantong University (03081171) and the Natural Science Foundation of Jiangsu Province (BK20190920).

\section{Author contributions}

QC and XYL performed the experiments, analyzed and interpreted the data, prepared figures. QC and and ZHT wrote the manuscript. HSX and GYW performed part of the experiments and data analysis. XRG and ZJ revised the article critically. All authors have read and approved the manuscript.

\section{Acknowledgments}

Not applicable

\section{References}

1. Paul, D., Lade, H. (2014). Plant-growth-promoting rhizobacteria to improve crop growth in saline soils: a review. Agronomy for Sustainable Development, 34, 737-752.

2. Oshone, R., Ngom, M., Chu, F., Mansour, S., Sy, M.O., Champion, A., Tisa, L.S. (2017). Genomic, transcriptomic, and proteomic approaches towards understanding the molecular mechanisms of salt tolerance in Frankia strains isolated from casuarina trees. BMC Genomics, 633-654.

3. Chen, H., Tao, L., Shi, J., Han, X., Cheng, X. (2021). Exogenous salicylic acid signal reveals an osmotic regulatory role in priming the seed germination of leymus chinensis under salt-alkali stress.

Environmental and Experimental Botany, 188104498.

4. Xu, Z.K., Shao, T.Y., Lv, Z.X., Yue, Y., Liu, A., Long, X.H., Zhou, Z.S., Gao, X.M., Rengel, Z. (2020). The mechanisms of improving coastal saline soils by planting rice. Science of The Total Environment, 703. 
5. Eloy, N.L., Valeria, P., Francisco, J.L.M., Juan, J.R., Sergio, E., Begoña, B. (2021). Effect of CAX1a TILLING mutations on photosynthesis performance in salt-stressed brassica rapa plants. Plant Science 311.

6. Li, J., Cao, F., Di, W., Xiao, F., Ye, T., Gang, W. (2018). Determining soil utrients reference condition in Alpine Region Grassland, China: a case study of Hulun Buir Grassland. Sustainability, 10, 1-12.

7. Meng, X., Zhao, Q., Jin, Y., Yu, J., Yin, Z., Chen, S., Dai, S. (2016). Chilling-responsive mechanisms in halophyte Puccinellia tenuiflora seedlings revealed from proteomics analysis. Journal of Proteomics, 143, 365-381.

8. Zelm, E.V., Zhang, Y., Testerink, C. (2020). Salt tolerance mechanisms of plants. Annual Review of Plant Biology, 71.

9. Jia, X.M., Hai, W., Svetla, S., Zhu, Y.F., Wang, Y.X. (2019). Comparative physiological responses and adaptive strategies of apple Malus halliana to salt, alkali and saline-alkali stress. Scientia Horticulturae, 245, 154-162.

10. Zhou, Z., Li, Z., Zhang, Z., You, L., Cui X. (2021). Treatment of the saline-alkali soil with acidic corn stalk biochar and its effect on the sorghum yield in western songnen plain. Science of The Total Environment, 797149190.

11. Fang, S., Hou, X., Liang, X. (2021). Response mechanisms of plants under saline-alkali stress. Frontiers in Plant Science 12.

12. Li, J., Hussain, T., Feng, X., Guo, K., Liu, X. (2019). Comparative study on the resistance of Suaeda glauca and Suaeda salsa to drought, salt, and alkali stresses. Ecological Engineering, 140, 105593 140:105593, DOI:10.1016/j.ecoleng.2019.105593.

13. Li, Q., Song, J. (2019). Analysis of widely targeted metabolites of the euhalophyte Suaeda salsa under saline conditions provides new insights into salt tolerance and nutritional value in halophytic species. BMC Plant Biology, 19, 388-349.

14. Lu, X., Chen, Q., Cui, X., Abozeid, A., Liu, Y., Liu, J., Tang, Z. (2021). Comparative metabolomics of two saline-alkali tolerant plants Suaeda glauca and Puccinellia tenuiflora based on GC-MS platform. Natural Product Research, 35, 499-502.

15. Pang, Q., Zhang, A., Zang, W., Wei, L., Yan, X. (2016). Integrated proteomics and metabolomics for dissecting the mechanism of global responses to salt and alkali stress in Suaeda corniculata. Plant \& Soil, 402, 379-394.

16. Ye, X., Wang, H., Cao, X., Jin, X., Cui, F., Bu, Y., Liu, H., Wu, W., Takano, T., Liu, S. (2019). Transcriptome profiling of Puccinellia tenuiflora during seed germination under a long-term saline-alkali stress. BMC Genomics, 20, 589-603.

17. Yin, Z., Zhang, H., Zhao, Q., Yoo, M.J., Zhu, N., Yu, J., Yu, J., Guo, S., Miao, Y., Chen, S. (2019). Physiological and comparative proteomic analyses of saline-alkali $\mathrm{NaHCO}_{3}$-responses in leaves of halophyte Puccinellia tenuiflora. Plant and Soil, 437, 137-158.

18. Wang, C., Zhang, J., Liu, X., Li, Z., Wu, G., Cai, J., Flowers, T., Wang, S. (2010). Puccinellia tenuiflora maintains a low $\mathrm{Na}^{+}$level under salinity by limiting unidirectional $\mathrm{Na}^{+}$influx resulting in a high 
selectivity for $\mathrm{K}^{+}$over $\mathrm{Na}^{+}$. Plant Cell \& Environment, 32, 486-496.

19. Chen, Q., Lu, X., Guo, X., Guo, Q., Li, D. (2017). Metabolomics characterization of two apocynaceae pants, Catharanthus roseus and Vinca minor, using GC-MS and LC-MS methods in combination. Molecule, 22, 997-1013.

20. Chen, Q., Lu, X., Guo, X., Xu, M., Tang, Z.J. (2021). A source-sink model explains the difference in the metabolic mechanism of mechanical damage to young and senescing leaves in Catharanthus roseus. BMC Plant Biology, 21, 154-168.

21. Miranda-Apodaca, J., Yoldi-Achalandabaso, A., Agirresarobe, Canto, A., Pérez-López, A.D.U. (2018). Similarities and differences between the responses to osmotic and ionic stress in quinoa from a water use perspective. Agricultural Water Management, 203.

22. An, Y., Yang, X., Zhang, L., Zhang, J., Guo, C. (2020). Alfalfa MsCBL4 enhances calcium metabolism but not sodium transport in transgenic tobacco under salt and saline-alkali stress. Plant Cell Reports, 39, 997-1031.

23. Jia, X.M., Zhu, Y.F., Hu, Y., Zhang, R., Wang, Y.X (2019). Integrated physiologic, proteomic, and metabolomic analyses of Malus halliana adaptation to saline-alkali stress. Horticulture Rsearch, $6,91-110$.

24. Llanes, A., Arbona, V., Gómez-Cadenas, A., Luna, V. (2016). Metabolomic profiling of the halophyte Prosopis strombulifera shows sodium salt-specific response. Plant Physiology \& Biochemistry, 108, 145-157.

25. Han, B., Fu, L., Zhang, D., He, X., Chen, Q., Ming, P., Zhang, J.M. (2016). Interspecies and intraspecies analysis of trehalose contents and the biosynthesis pathway gene family reveals crucial roles of trehalose in osmotic-stress tolerance in Cassava. International Journal of Molecular Sciences, 17, 1077-1095.

26. Mostofa, M.G., Hossain, M.A., Fujita, M. (2015). Trehalose pretreatment induces salt tolerance in rice (Oryza sativa L.) seedlings: oxidative damage and co-induction of antioxidant defense and glyoxalase systems. Protoplasma, 252, 461-475.

27. Wang, H., Takano, T., Liu, S. (2018). Screening and evaluation of saline-alkaline tolerant germplasm of rice (oryza sativa I.) in soda saline-alkali soil. Agronomy 8205.

28. Qin, L., Wang, L., Guo, Y., Li, Y., Halik, ü., Wang, Y. (2017). An ERF transcription factor from tamarix hispida, thcrf1, can adjust osmotic potential and reactive oxygen species scavenging capability to improve salt tolerance. Plant Science 265.

29. Lucas, D.Á.S., Condori, J., Marcelino, M.M., Tavares, A., Raimundi,S.C.J., Martino, P.B., Wagner, L.A., Agustin, Z., Ronan, S., Adriano, N.N. (2019). Nitrogen differentially modulates photosynthesis, carbon allocation and yield related traits in two contrasting capsicum chinense cultivars. Plant Science, 283 224-237.

30. Joshi, V., Fernie, A. (2017). Citrulline metabolism in plants. Amino Acids, 49, 1543-1559.

31. Rui, G., Yang, Z., Feng, L., Yan, C., Zhong, X., Qi, L., Xu, X., Li, H., Long, Z. (2015). Comparative metabolic responses and adaptive strategies of wheat (Triticum aestivum) to salt and alkali stress. 
BMC Plant Biology, 15, 170-183.

32. Sang, T., Shan, X., Li, B., Shu, S., Sun, J., Guo, S. (2016). Comparative proteomic analysis reveals the positive effect of exogenous spermidine on photosynthesis and salinity tolerance in cucumber seedlings. Plant Cell Reports, 35, 1769-1782.

33. Liu, B., Peng, X., Han, L., Hou, L., Li, B. (2020). Effects of exogenous spermidine on root metabolism of cucumber seedlings under salt stress by GC-MS. Agronomy, 10, 459-481.

34. Singh, R., Gupta, P., Khan, F., Singh, S., Sanchita, Mishra, T., Kumar, A., Dhawan, S.S., Shirke, P. (2018) Modulations in primary and secondary metabolic pathways and adjustment in physiological behaviour of withania somnifera under drought stress. Plant Science 272 42-54.

35. Hancock, C.N., Phang, J. (2012). Abstract 1119: The oxidation of proline by proline oxidase provides a regulated source of ROS for mitochondria derived cellular signaling. Cancer Research, 72, 1119, DOI:10.1158/1538-7445.AM2012-1119.

36. Jin, J., Cui, X., Wu, J., Wang, J., Wang, G. (2011). Physiological and biochemical responses of halophyte Kalidium foliatum to salt stress. African Journal of Biotechnology, 10, 11468-11476.

37. Li, H., Tang, X., Yang, X., Zhang, H. (2021). Comprehensive transcriptome and metabolome profiling reveal metabolic mechanisms of nitraria sibirica pall. to salt stress. Scientific Reports 1112878.

38. Apa, B., Jra, B., Akpa, B. (2020). Unraveling salt responsive metabolites and metabolic pathways using non-targeted metabolomics approach and elucidation of salt tolerance mechanisms in the xero-halophyte Haloxylon salicornicum-ScienceDirect. Plant Physiology and Biochemistry, 158, 284296.

39. Guo, S.H., Niu, Y.J., Zhai, H., Han, N., Du, Y.P. (2018). Effects of alkaline stress on organic acid metabolism in roots of grape hybrid rootstocks. Scientia Horticulturae, 227, 255-260.

40. Rudack, K., Seddig, S., Sprenger, H., Köhl, K.. Ordon, F. (2017). Drought stress-induced changes in starch yield and physiological traits in potato. Journal of Agronomy and Crop Science, 203, 494505.

41. Cook, S.D. (2019). An historical review of phenylacetic acid. Plant and Cell Physiology, 243-254.

42. Almeida, T., Pinto, G., Correia, B., Gonçalves, S., Meijón, M., Escandón, M. (2020). In-depth analysis of the quercus suber metabolome under drought stress and recovery reveals potential key metabolic players. Plant Science, 299110606.

43. Corso, M. Perreau, F., Mouille, G., Lepiniec, L. (2020). Specialized phenolic compounds in seeds: structures, functions, and regulations-sciencedirect. Plant Science, 296110471.

44. Sarker, U., Oba, S. (2018). Drought stress enhances nutritional and bioactive compounds, phenolic acids and antioxidant capacity of amaranthus leafy vegetable. BMC Plant Biology, 18, 258-173.

45. Sharma, A., Shahzad, B., Rehman, A., Bhardwaj, R., Zheng, B. (2019). Response of phenylpropanoid pathway and the role of polyphenols in plants under abiotic stress. Molecules, 24, 2452.

46. Liu, Y., Liu, J., Abozeid, A., Wu, K.X., Tang, Z.H. (2020b). UV-B radiation largely promoted the transformation of primary metabolites to phenols in Astragalus mongholicus seedlings. 
Biomolecules, 10, 504-525.

\section{Supplemental Figure}

Supplemental Figure $\mathrm{S} 1$ is not available with this version.

\section{Figures}

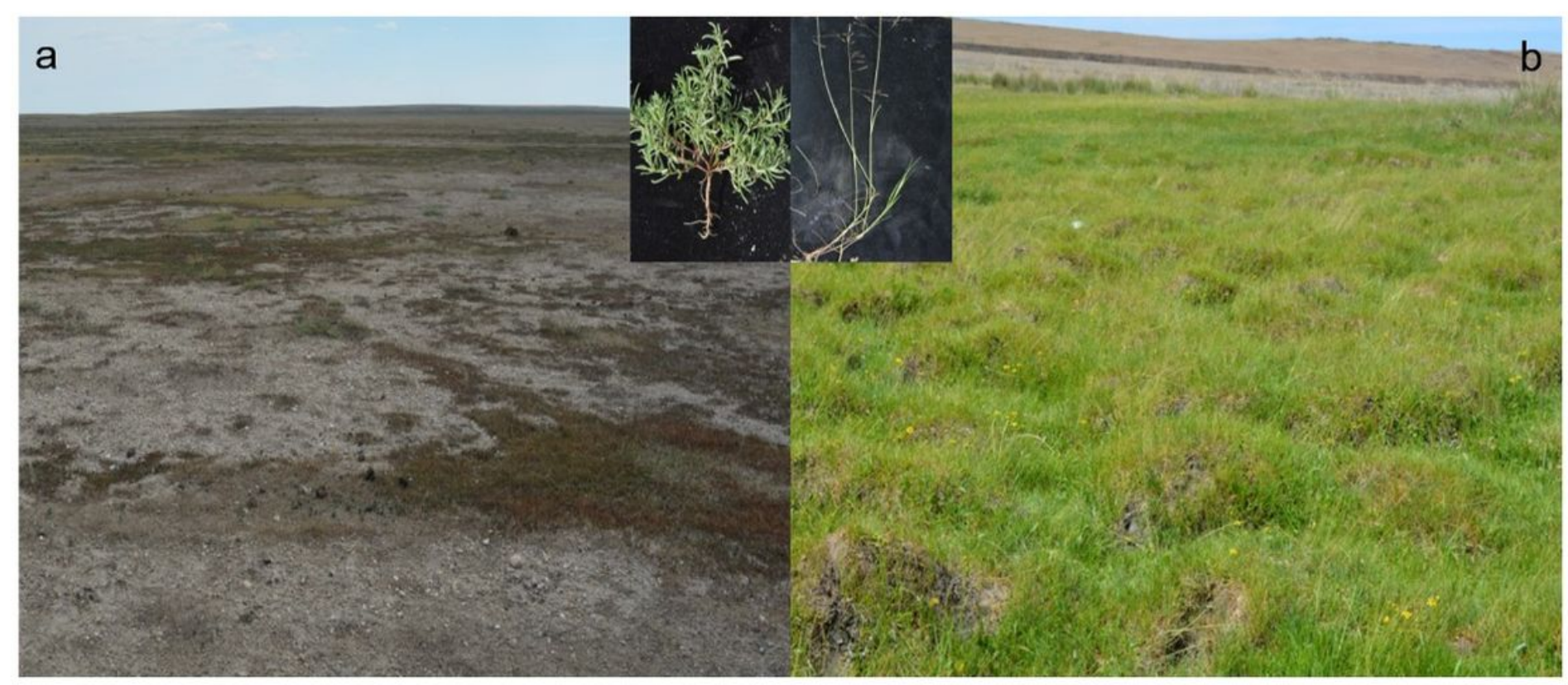

\section{Figure 1}

The appearance of S. salsa community and P. tenuiflora community. (a) S. salsa community and S. salsa; (b) P. tenuiflora community and P. tenuiflora. 

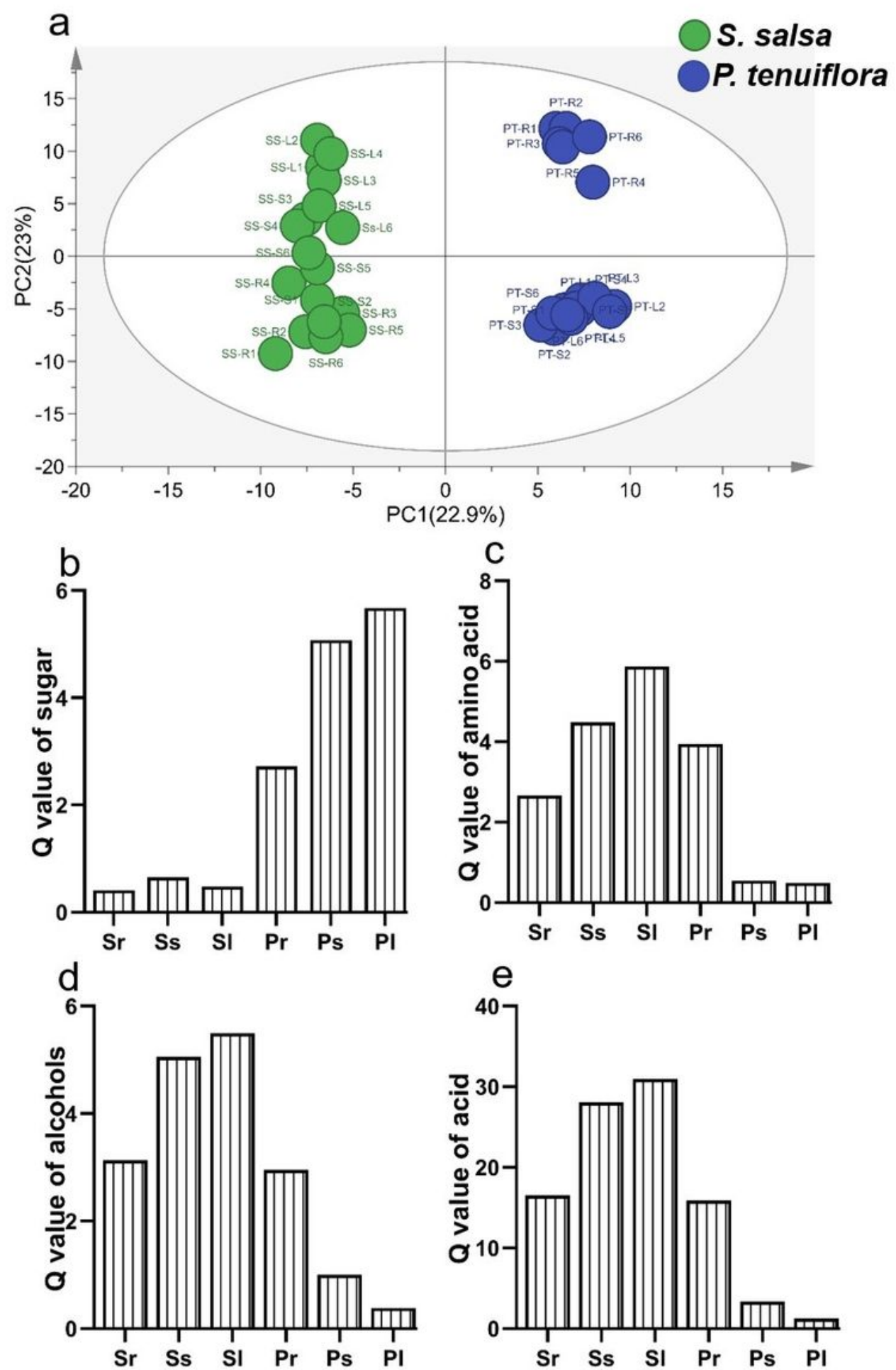

Figure 2

The OPLS-DA score plot of primary metabolites and the $Q$ value of them significantly metabolites between S. salsa and P. tenuiflora. (a) The OPLS-DA score plot of primary metabolites; (b) Q value of sugar; (c) Q value of amino acid; (d) Q value of alcohol; (e) Q value of acids. Sr: the root of S. salsa. Ss: the stem of S. salsa. Sl: the leaf of S. salsa. Pr: the root of P. tenuiflora. Ps: the stem of P. tenuiflora. PI: the leaf of P. tenuiflora. 


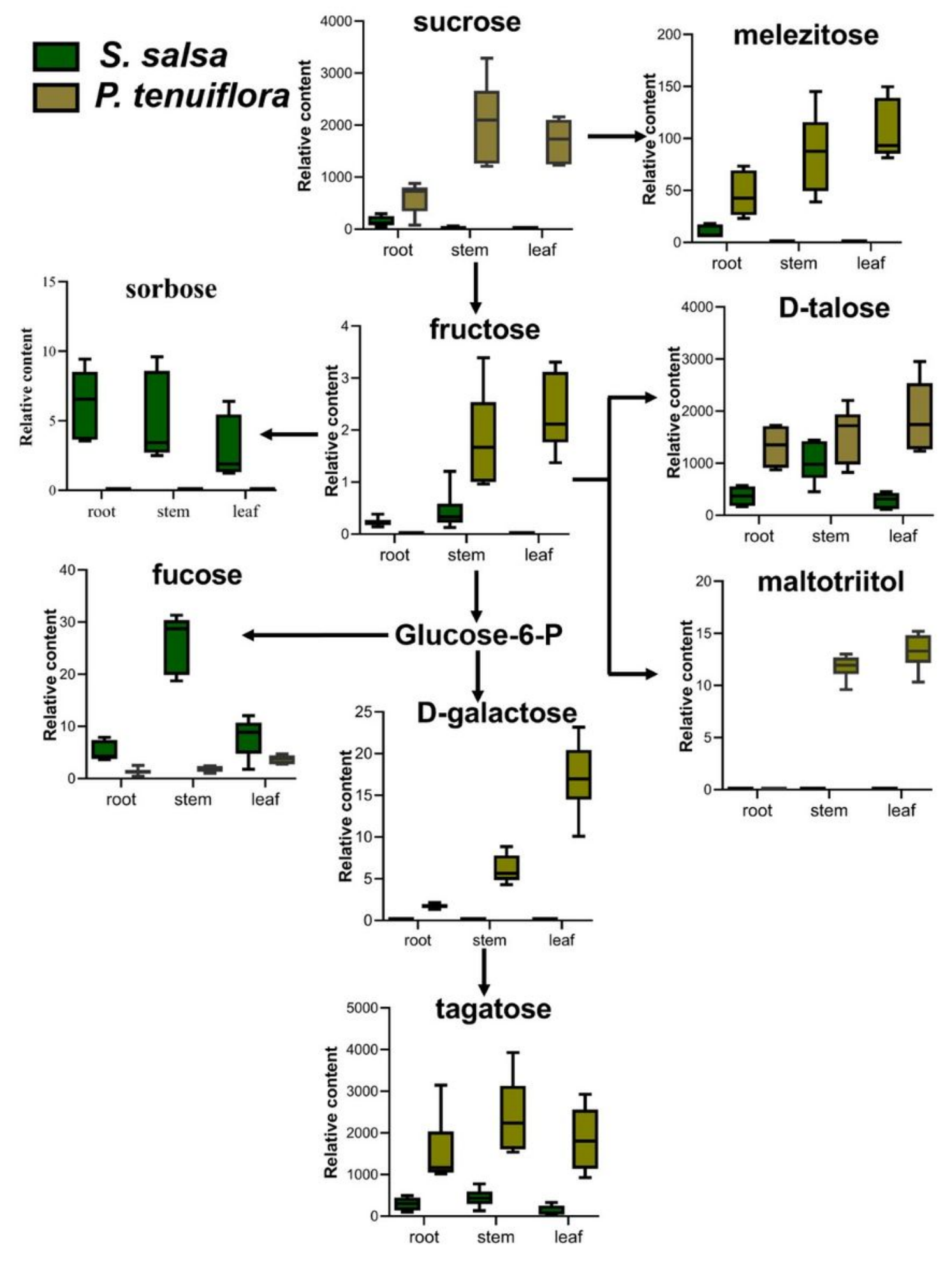

Figure 3

The metabolic network of significantly sugars between S. salsa and P. tenuiflora. 


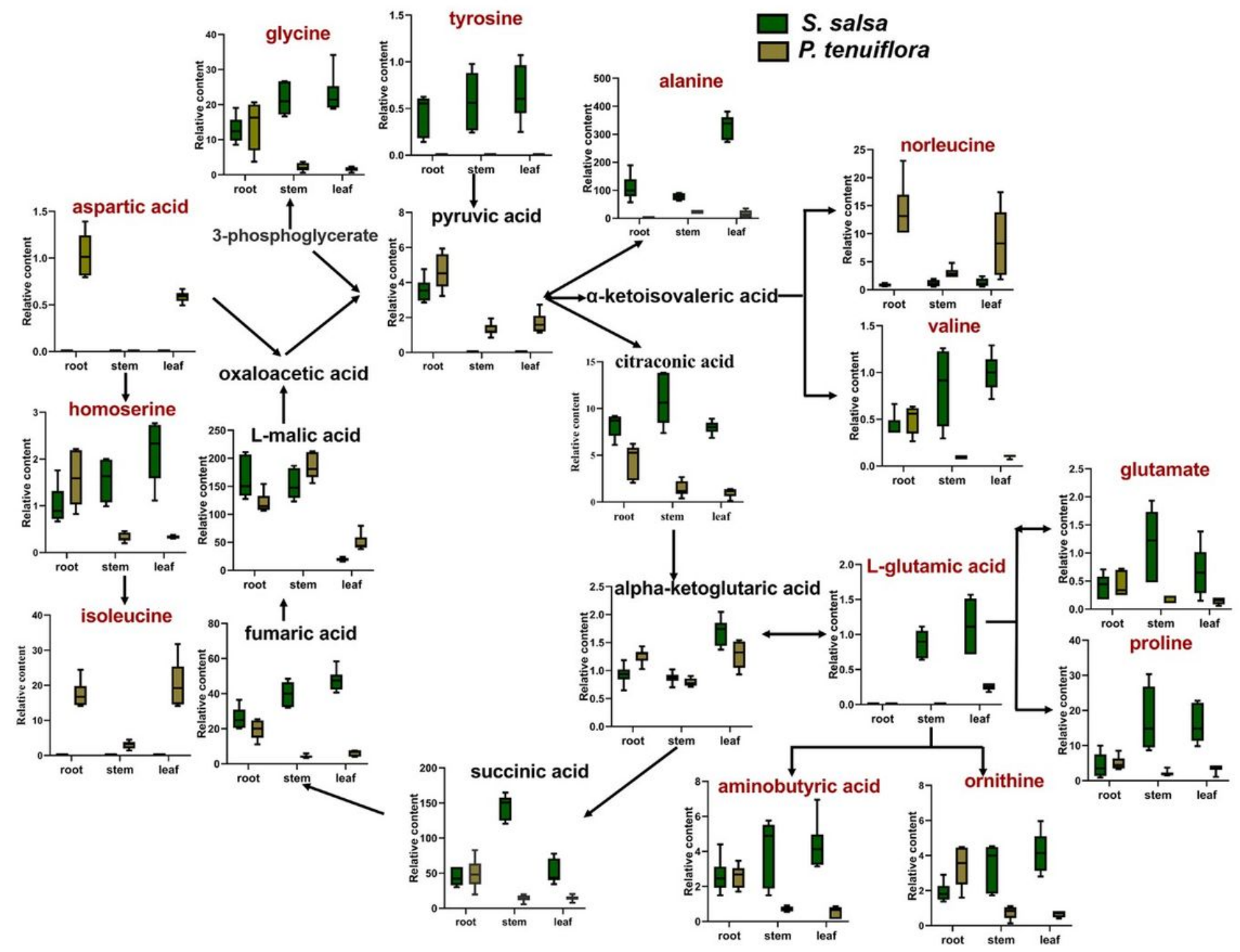

Figure 4

The metabolic network of amino acids between S. salsa and P. tenuiflora. The significantly different metabolites were marked red. 

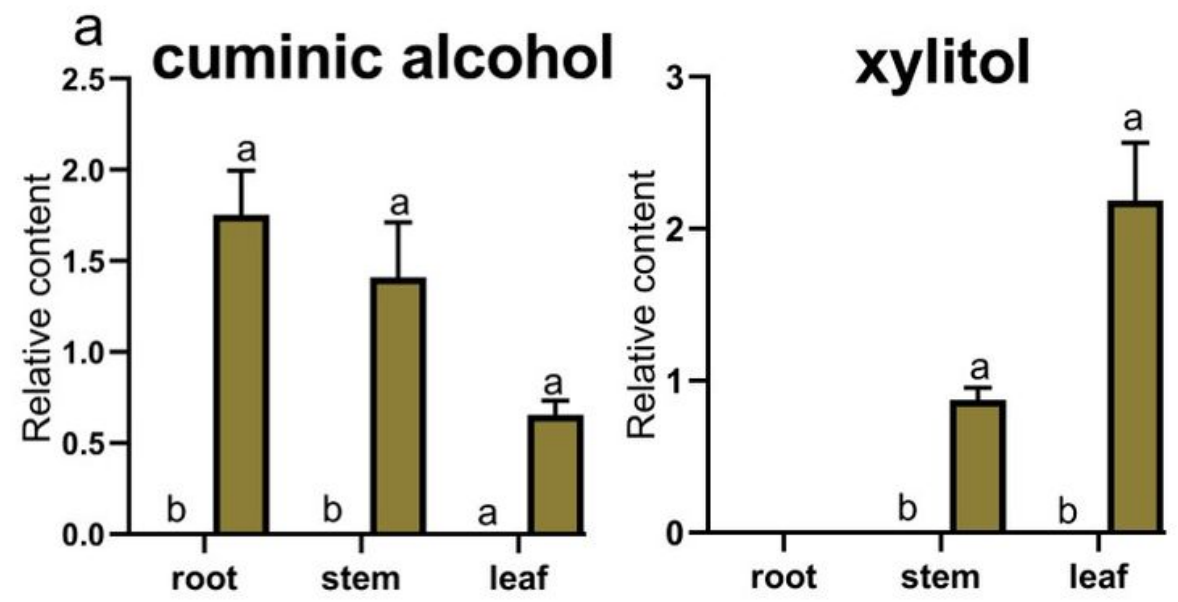

S. salsa

P. tenuiflora
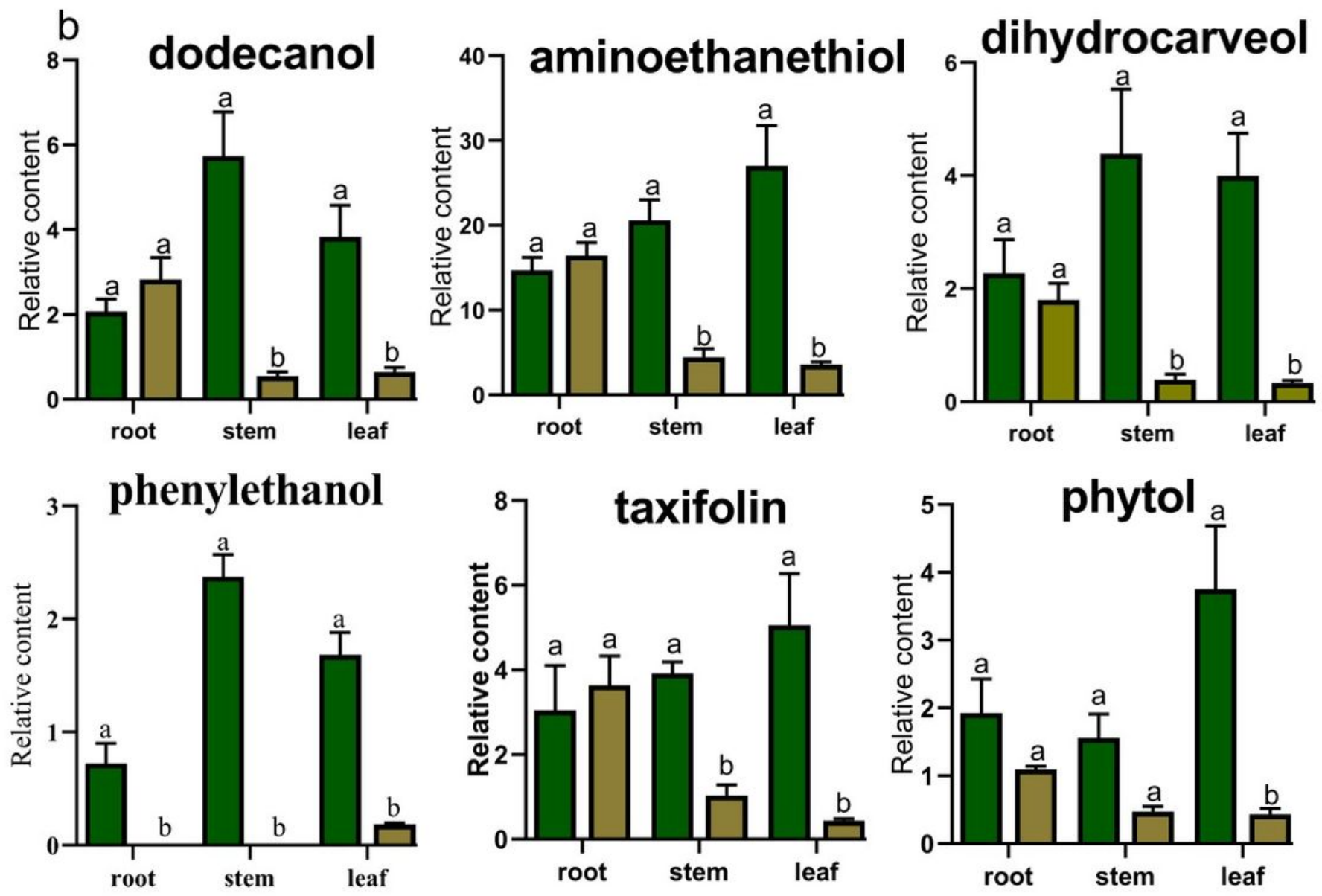

\section{Figure 5}

The significantly different alcohols between S. salsa and P. tenuiflora. (a) The significantly different alcohols mainly accumulated in P. tenuiflora; (b) The significantly different alcohols mainly accumulated in S. salsa. The relative contents of significantly different alcohols are summarized from 6 biological replicates and presented as the mean \pm standard error of 6 biological replicates. Different letters indicate significant differences among treatments $(p<0.05)$. 


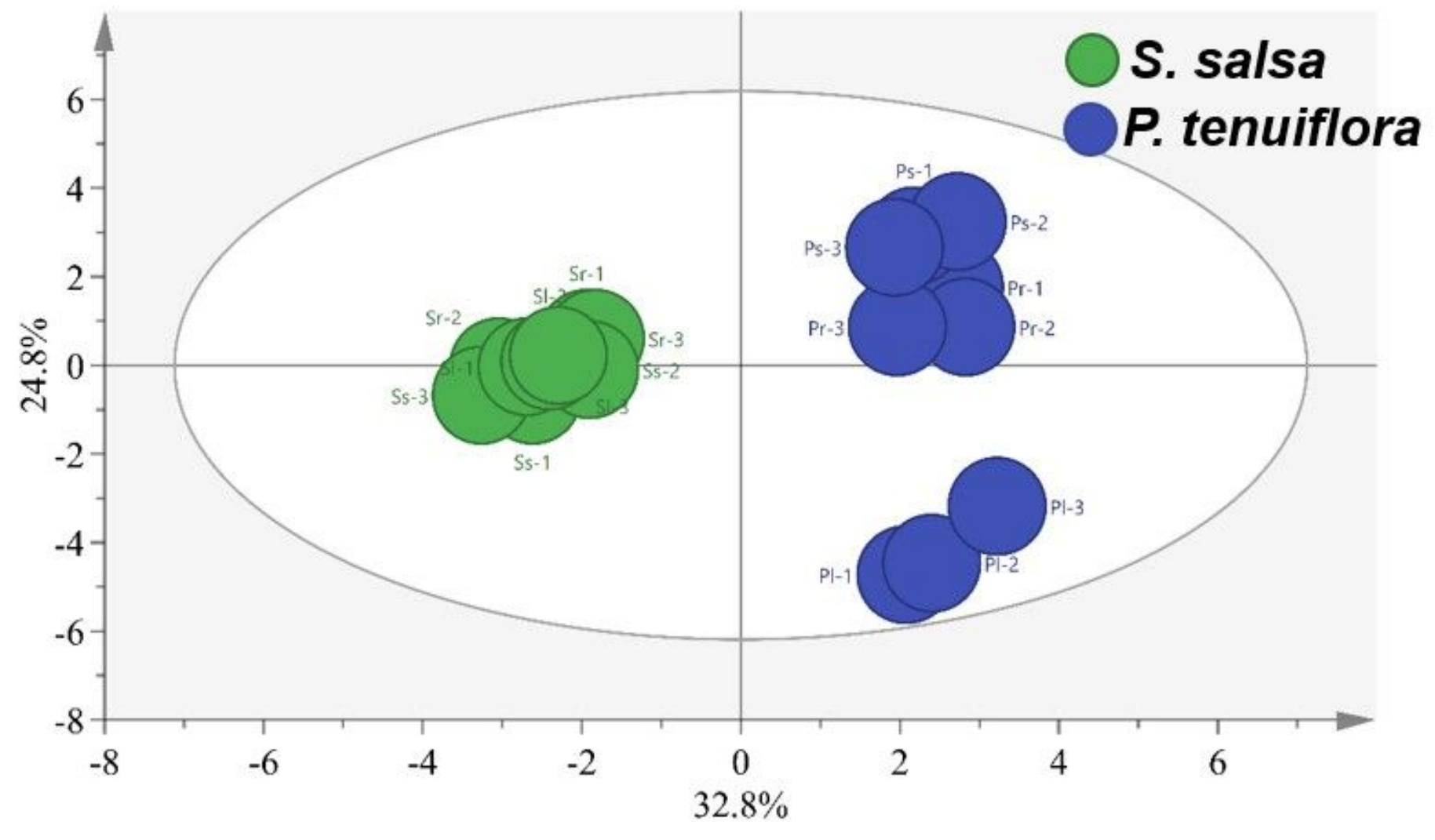

Figure 6

The OPLS-DA score plot of phenolic compounds. 


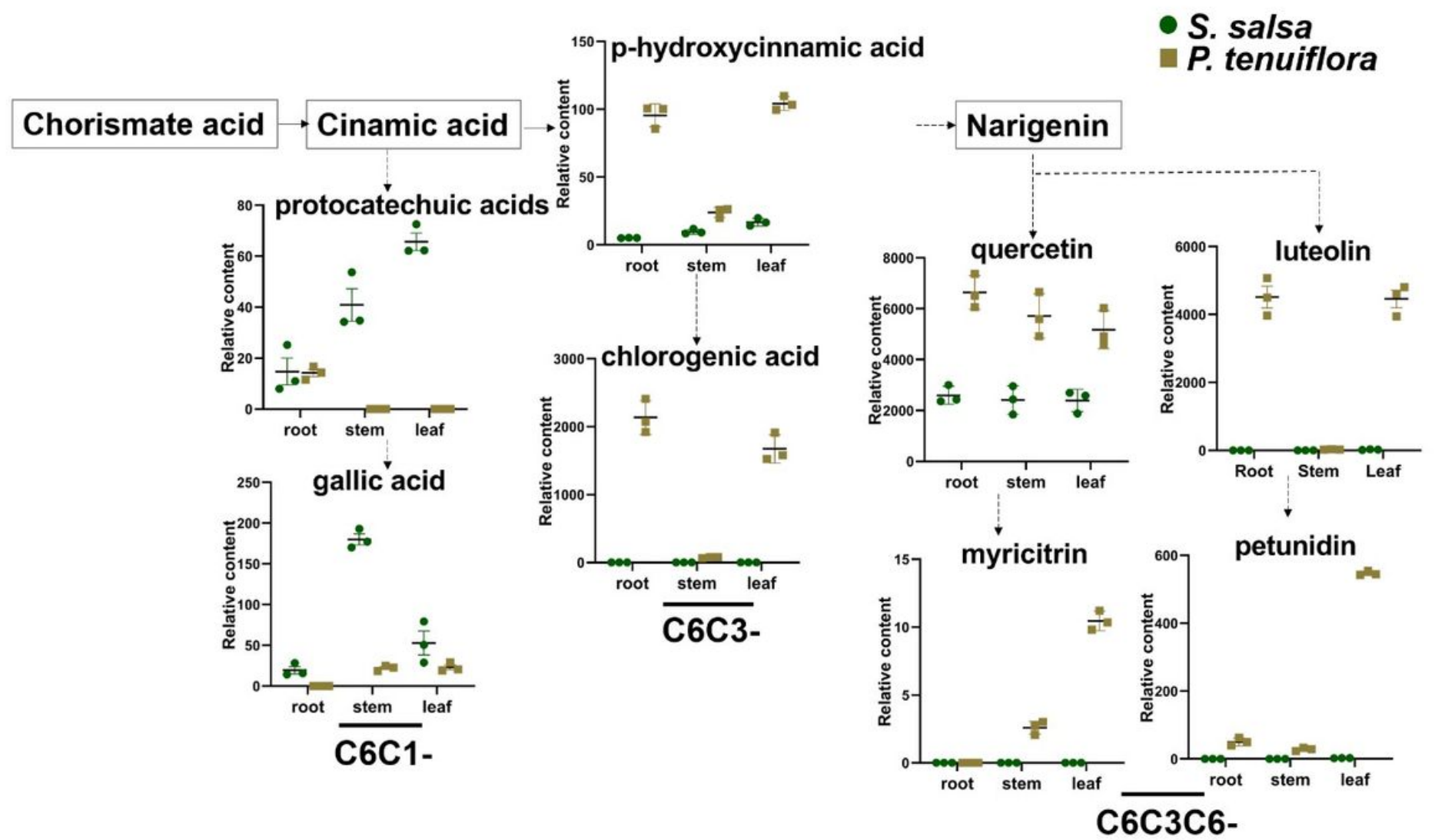

Figure 7

Visualization of the difference of significantly phenolic compounds on a biochemical pathway map.

\section{Supplementary Files}

This is a list of supplementary files associated with this preprint. Click to download.

- supplemental.docx 